\title{
PENERAPAN MODEL PEMBELAJARAN THINK PHAIR SHARE UNTUK MENINGKATKAN HASIL BELAJAR MATA PELAJARAN IPA PADA SISWA KELAS 4 SDIT QA BAITUSALLAM
}

\author{
Sulastri Ismail Bethan 1*, Imas Kania Rahman², Muhammad Fahri ${ }^{3}$ \\ 1,2,3Universitas Ibn Khaldun Bogor, Indonesia \\ Email : ${ }^{1 *}$ larasbethan@gmail.com
}

\begin{abstract}
ABSTRAK
Proses pembelajaran dapat dikatakan mencapai tujuan pembelajaran apabila hasil belajar dan aktivitas belajar siswa meningkat dari tahap ke tahap. Namun hal tersebut tidak dijumpai pada saat pembelajaran IPA di kelas IV SDIT QA Baitusallam hal tersebut diketahui dengan menggunakan soal yang diberikan kepada siswa melalui google form. soal yang diberikan kepada siswa tersebut kemudian dinilai, dari hasil penilaian tersebut peneliti menyimpulkan bahwa proses pembelajaran IPA yang ada di SDIT QA Baitusallam kurang efektif. Dari permasalahan tersebut peneliti tertarik melakukan penelitian tindakan kelas dengan model pembelajaran think phair share pada mata pelajaran IPA dikelas IV SDIT QA Baitusallam. Penilitian dilakukan dengan menggunakan 2 siklus. Dari kedua siklus tersebut peneliti menemukan peningkatan dari siklus 1 dan siklus 2 . Hasil dari setiap siklus tersebut peneliti menyimpulkan bahwa model pembelajaran think phair share pada matapelajaran IPA di kelas IV SDIT QA Baitusallam mengalami peningkatan.
\end{abstract}

Kata kunci: model pembelajaran, think phair share, hasil belajar

\begin{abstract}
The learning process can be said to achieve learning objectives if the learning outcomes and student learning activities increase from stage to stage. However, this was not found when learning science in grade IV SDIT QA Baitusallam. This is known from the results of students answering questions given by google form. The questions given to these students are then assessed, and based on the results of assessment researcher can conclud that the science learning process in SDIT QA Baitusallam was less effective. Based on these problems, researchers are interested in conducting classroom action research with think phair share learning model in science subjects in grade IV SDIT QA Baitusallam. The research was conducted using 2 cycles. From the two cycles, the researcher found an increase from the first cycle to the second cycle. Thus it can be concluded that using the think phair shared learning model can improve learning outcomes in science subjects in grade IV SDIT QA Baitusallam.
\end{abstract}

Keywords: learning model, think phair share, learning outcomes. 


\section{Pendahuluan}

Pendidikan merupakan kebutuhan pokok manusia, dan memiliki peranan yang sangat besar dalam mensukseskan bangsa. Dalam dunia pendidikan, keterampilan berbahasa, keterampilan membaca, dan keterampilan menulis merupakan modal awal siswa untuk mempelajari pengetahuan lain yang dikembangkan dalam pendidikan formal. Dengan pendidikan seseorang bisa menjadi lebih baik untuk dirinya ataupun orang lain karena memiliki wawasan yang lebih dibandingkan dengan yang tidak berpendidikan, peran yang terpenting untuk meningkatkan suatu pendidikan adalah guru atau seorang pendidik. Salah satunya adalah keberhasilan proses pembelajaran dikelas ditentukan dari kualitas dan keterampilan seorang guru. Karena guru adalah orang yang bisa meningkatkan kualitas pendidikan dan pembelajaran. Sedangkan menurut Susanto (2014:18-19) "Kata pembelajaran merupakan perpaduan dari dua aktivitas belajar dan mengajar. Aktivitas belajar secara metodologis cenderung lebih dominan pada siswa, sementara mengajar secara tingkah laku siswa”.

Pembelajaran hakikatnya adalah usaha sadar dari seorang guru untuk membelajarkan atau mendidik siswanya dalam rangka mencapai tujuan yang diharapkan. Dari makna tersebut terlihat bahwa pembelajaran terjadi karena interaksi antara guru dengan siswa dalam komunikasi yang terarah dan intens sehingga tercapai tujuan pembelajaran. Guru sebagai ujung tombak keberhasilan siswa tentu harus melaksanakan pembelajaran dengan berbagai metode atau model pengajaran didalam kelas sehingga siswa tidak bosan dalam mengikuti kegiatan pembelajaran. Dalam proses pembelajaran tentu banyak mata pelajaran yang disajikan untuk berlangsungnya proses belajar mengajar. Salah satu diantaranya adalah pelajaran Ilmu Pengetahuan Alam (IPA). Ilmu Pengetahuan Alam merupakan rumpun ilmu, memiliki karakteristik khusus yaitu mempelajari fenomena alam yang factual (factual), baik berupa kenyataan (reality) atau kejadian ( events) dan hubungan sebab- akibatnya (Sulistyowati, 2014:22).

Menurut Trianto (2013:) Pembelajaran IPA dapat memberikan pengetahuan (kognitif), yang merupakan tujuan utama dari pembelajaran. Jenis pengetahuan yang dimaksud adalah pengetahuan dasar dari prinsip dan konsep yang bermaanfaat untuk kehidupan sehari-hari.

Berbagai model pembelajaran yang dilakukan oleh seorang guru pada umumnya untuk membantu siswa agar mampu memahami dan mengerti apa yang dipelajarinya. Salah satu model pembelajaran yang menjadi alternatif adalah dengan menggunakan atau menerapkan model pembelajaran Think Pair Share.

Berdasarkan hasil observasi dikelas IV SDIT QA Baitussalam terdapat beberapa kendala dalam proses pembelajaran Ilmu Pengetahuan Alam (IPA) yaitu: Dalam pembelajaran IPA ,guru belum maksimal dalam penggunaan metode pembelajaran, Rendahnya aktivitas belajar siswa memahami materi karena guru kurang menggunakan media yang kreatif ,dan hasil belajar siswa yang belum mencapai nilai diatas KKM (Kriteria Ketuntasan Maksimum), 
Berdasarkan penjelasan masalah diatas, maka masalah yang diambil dalam penelitian ini dirumuskan sebagai "Bagaimana Peningkatan Hasil Belajar Pembelajaran Ilmu Pengetahuan Alam IPA melalui penerapan Model Pembelajaran Think Pair Share pada kelas IV di SDIT QA Baitusallam?".

\section{Metode Penelitian}

Dalam penelitian ini, penelitian menggunakan Penlitian Tindakan Kelas (PTK). Penelitian tindakan kelas (PTK) berasal dari istilah bahasa Inggris Classroom Action Research, yang berarti penelitian yang dilakukan atau dilaksanakan pada sebuah kelas untuk mengetahui akibat tindakan yang diterapkan pada suatu subyek penelitian dikelas tersebut. Pertama kali penelitian tindakan kelas ini diperkenalkan oleh ahli psikologi sosial Amerika Serikat Kurt Lewin pada tahun 1946, dan selanjutnya dikembangkan oleh Stephen Kemmis, Robin Mc Taggart, John Elliot, Dave Ebbut dan lainnya (Trianto, 2012:13).

Dalam melaksanakan Penelitian Tindakan Kelas penulis memulai dengan empat langkah utama yaitu perencanaan, pelaksanaan, pengamatan dan refleksi. Berikut tahapan model penelitian tindakan kelas :

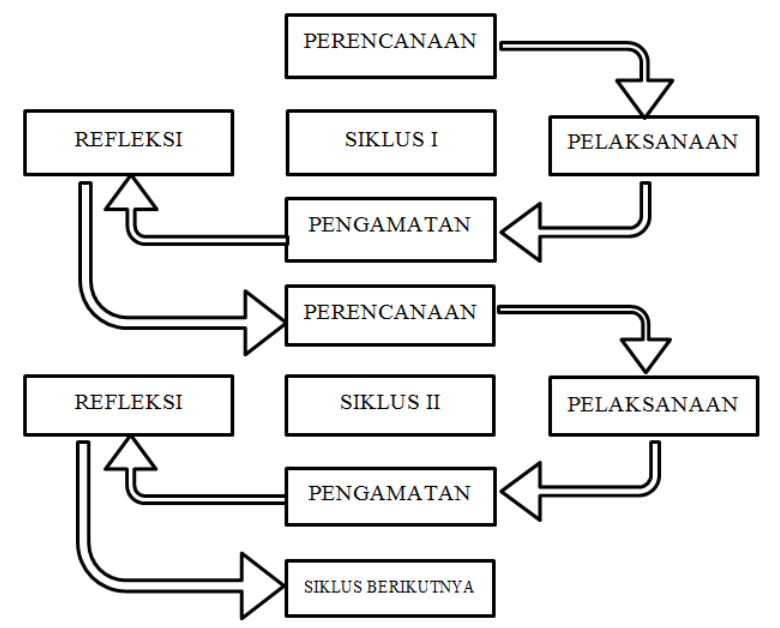

\section{Gambar 3.1 Model Penelitian Tindakan Kelas menurut Suharsimi Arikunto}

\section{Hasil dan Pembahasan}

Penelitian tindakan kelas ini telah dilaksanakan secara keseluruhan maka yang diperoleh dari hasil pengamatan pada pra siklus yang dilakukan oleh observer dalam aktivitas guru selama pembelajaran berlangsung yaitu 45,65\% Sedangkan dalam aktivitas siswa selama pembelajaran berlangsng yaitu 70\%, selain itu dari 29 siswa 14 siswa yang belum berhasil dan 15 siswa yang sudah tuntas, dengan nilai rata-rata $57,51 \%$. Karena itu, masih ada beberapa siswa yang belum mencapai ketuntasan belajar, sehingga perlu adanya penilaian tindakan siklus 2 untuk perbaikan.

Penelitian tindakan kelas siklus 2 data yang diperoleh hasil pengamatan yang dilakukan oleh observer dalam aktivitas guru selama berlangsung 75\%, hal ini mengalami 
peningkatan dari siklus 1 57,51\% menjadi 78,4 di siklus 2, sedangkan aktivitas siswa selama pembelajaran berlangsung yaitu $75 \%$, hal ini pun mengalami penigkatan dari siklus $145 \%$ menjadi $75 \%$ di siklus 2 . Selain itu, dari 29 siswa terdapat 29 siswa yang sudah tuntas, dengan rata-rata 78,4\%. Ini menunjukan adanya peningkatan hasil belajar dari pra siklus 45,65\%, siklus 1 57,51 dan siklus 2 menjadi 78,4.

Berdasarkan pembahasan tersebut, penelitian tindakan kelas yang dilaksanakan di kelas IV melalui model pembelajaran Think Pair Share pada pra siklus, siklus 1, dan siklus 2 mengalami peningkatan disetiap siklusnya, baik dari aktivitas guru, aktivitas siswa, maupun hasil belajar.

Hal ini dapat dilihat dari table peningkatan aktivitas guru, aktivitas siswa, dan hasil belajar Ilmu Pengetahuan Alam melalui penerapan model pembelajaran Think Pair Share sebagai berikut :

Tabel 1

\section{Penginkatan Aktivitas Guru Selama Proses Pembelajaran}

\begin{tabular}{|c|c|c|}
\hline Siklus & Presentase & Kriteria \\
\hline 1 & $45,65 \%$ & Cukup Baik \\
\hline 2 & 57,51 & Baik \\
\hline 3 & 78,4 & Sangat Baik \\
\hline
\end{tabular}

Tabel 2

Peningkatan Aktivitas Siswa Selama Proses Pembelajaran

\begin{tabular}{|c|c|c|}
\hline Siklus & Presentase & Kriteria \\
\hline & $45 \%$ & Cukup Baik \\
\hline & $70 \%$ & Baik \\
\hline & $75 \%$ & Baik \\
\hline
\end{tabular}

Tabel 3

Peningkatan Ketuntasan Hasil Belajar Ilmu Pengetahuan Alam Pada Pembelajaran Pra siklus, siklus 1, dan siklus 2

\begin{tabular}{|c|c|c|c|c|}
\hline \multirow{2}{*}{ No } & Kriteria & \multicolumn{3}{|c|}{ Jumlah } \\
\cline { 3 - 5 } & & Pra siklus & Siklus 1 & Siklus 2 \\
\hline & Tuntas & 0 & 15 & 29 \\
\hline & Belum Tuntas & 0 & 14 & 0 \\
\hline
\end{tabular}




\section{Tabel 4}

\section{Peningkatan Nilai Rata-rata Hasil Belajar Ilmu Pengetahuan Alam}

Pra siklus, Siklus 1 dan Siklus 2

\begin{tabular}{|c|c|c|}
\hline \multicolumn{3}{|c|}{ Nilai Rata-rata } \\
\hline Pra siklus & Siklus 1 & Siklus 2 \\
\hline 45,65 & 57,51 & 78,4 \\
\hline
\end{tabular}

Berdasarkan hasil penelitian yang sudah dikemukakan dapat disimpulkan bahwa penerapan model pembelajaran Think Pair Share yang sudah diterapkan dalam proses pembelajaran merupakan salah satu alternatif dalam upaya peningkatan hasil belajar siswa pada mata pelajaran Ilmu Pengetahuan Alam.

\section{KESIMPULAN}

Berdasarkan hasil penelitian yang telah dilaksanakan tentang penerapan model pembelajaran Think Phair Share untuk meningkatkan hasil belajar mata pelajaran IPA pada siswa kelas IV SDIT QA Baitusallam dapat disimpulkan bahwa penerapan model pembelajaran Think Phair Share pada mata pelajaran IPA kelas IV SDIT QA Baitusallam ini efektif untuk meningkatkan hasil dan proses belajar siswa. Hal tersebut dapat dilihat melalui Pembelajaran yang dilaksanakan menggunakan 2 siklus dimana terdapat siklus 1 dan siklus 2 dari kedua siklus tersebut peneliti menemukan bahwa proses pembelajaran IPA pada siswa kelas IV SDIT QA Baitusallam dengan menggunakan metode Think Phair Share sangat afektif.

\section{Daftar Pustaka}

Susanto, Ahmad. 2014. Teori Belajar dan Pembelajaran di Sekolah Dasar. Jakarta : Prenadamedia Group

Sulistyowati, Eka. 2014. Metodologi Pembelajaran Ipa. Jakarta : PT Bumi Aksara.

Trianto. 2011. Panduan Lengkap Penelitian Tindakan Kelas.Jakarta : PRESTASI PUSTAKARAYA. 